\title{
Seeking Joint Development in the East China Sea
}

\author{
Keyuan Zou*
}

\section{Introduction}

The East China Sea is categorized as a semi-enclosed sea in East Asia under the general definition set forth in the United Nations Convention on the Law of the Sea (LOSC). ${ }^{1}$ Accordingly, "enclosed or semi-enclosed sea" is defined as "a gulf, basin, or sea surrounded by two or more States and connected to another sea or the ocean by a narrow outlet or consisting entirely or primarily of the territorial seas and exclusive economic zones of two or more coastal States". ${ }^{2}$ It covers about 480,000 sq mi $(1,243,190 \mathrm{sq} \mathrm{km})$ and is bounded by the islands of Cheju (north), Kyushu (northeast), Ryukyu (east) and Taiwan (south) and by China (west). ${ }^{3}$ It is a marginal sea with a wide continental shelf, and its average depth is 370 metres with the maximum of 2,719 metres. In recent years, the East China Sea is not quiet not only in its tidal waves or natural movements, but also in political and legal differences particularly between China and Japan.

With its ever increasing economic growth, China (PRC) is thirsty for energy particularly oil and gas so as to sustain its development. It became the world's second-largest net importer of crude oil and petroleum products in 2009 and the U.S. Energy Information Administration (EIA) projects that China will surpass the United States as the largest net oil importer by 2014. ${ }^{4}$ The China National Offshore Oil Corporation (CNOOC) - the third largest stateowned oil company in China - is responsible for offshore oil and gas exploration and production. It has been operating petroleum activities in the South China Sea, mainly adjacent to Hainan Island and Hong Kong, such as Weizhou, Huizhou, Lufeng, Dongfang

\footnotetext{
* It is acknowledged that this chapter is a variant version of a chapter by the same author published in Clive Schofield, Young Kil Park and Leonardo Bernard (eds.), East China Sea: How to Build Confidence and Promote Cooperation (Korea: Korea Maritime Institute, 2017), 202-224.

${ }^{1}$ The LOSC was adopted in the Third United Nations Conference on the Law of the Sea on 10 December 1982 and entered into force on 16 November 1994. Text is printed in The Law of the Sea: Official Text of the United Nations Convention on the Law of the Sea with Annexes and Index (New York: United Nations, 1983).

2 Art. 122 of the LOSC.

3 "East China Sea", in The New Encyclopaedia Britannica, 15th Edition, Vol.3 (Encyclopaedia Britannica, Inc., 1984), at 756.

4 US Energy Information Administration, "China”, Country Analysis, 4 February 2014, available at http://www.eia.gov/countries/analysisbriefs/China/china.pdf.
} 
oil/gas fields. CNOOC had increased its production to 20 percent of China's total petroleum production by $2010 .^{5}$

\section{General Legal Framework}

The concept of Joint Development first appeared in international law in the 1970s. There are various definitions on Joint Development in relevant legal literature. An earlier definition was offered by Rainer Lagoni, a German scholar and he defined Joint Development as "cooperation between States with regard to the exploration for and exploitation of certain deposits, fields, or accumulations of non-living resources which either extend across a boundary or lie in an area of overlapping claims". ${ }^{6}$ Gault defines Joint Development as "a decision by one or more countries to pool any rights they may have over a given area and, to a greater or lesser degree, undertake some form of joint management for the purpose of exploring and exploiting offshore minerals". ${ }^{7}$ Another pioneering scholar in the field of Joint Development studies is William T. Onorato, who published an article in 1968 discussing the idea of joint development. ${ }^{8}$ A further article of the same title was published again in the same journal in $1977 .{ }^{9}$ His most important point is that the old doctrine that a potential common petroleum deposit should be directed to the preservation of the "unity of the deposit", "or, more exactly, to unity of national ownership and exploitation authority over it" was out of date and such deposit can be accepted as joint property of several states under which it might lie. ${ }^{10}$ Though no definition on Joint Development is contained in these articles, the notion of the shared property, in particular concerning its apportionment, indicates the possibility of joint development between states concerned. Miyoshi even observed, the original idea of joint development can be traced back to as early as "1930s when studies and judicial cases on

\footnotetext{
${ }^{5}$ For details, see Zou Keyuan, "China's Governance over Offshore Oil and Gas Development and Management", Ocean Development and International Law, Vol.35 (4), 2004: 339-364.

6 See International Law Association, Report on Joint Development of Non-Living Resources in the Exclusive Economic Zone, 1988, at 2.

7 I.T. Gault, "Joint Development of Offshore Mineral Resources - Progress and Prospects for the Future", Mineral Resources Forum, Vol. 12 (3), 1988, at 275; cited in British Institute of International and Comparative Law, Joint Development of Offshore Oil and Gas: A Model Agreement for States for Joint Development with Explanatory Commentary (London: British Institute of International and Comparative Law, 1989), at 43.

${ }^{8}$ See William T. Onorato, "Apportionment of an International Common Petroleum Deposit", International and Comparative Law Quarterly, Vol.17, 1968, 85-101.

${ }^{9}$ See William T. Onorato, “Apportionment of an International Common Petroleum Deposit", International and Comparative Law Quarterly, Vol.26, 1977, 324-337.

${ }^{10}$ See Onorato, ibid., at 325.
} 
joint petroleum development can be found in the United States". ${ }^{11}$ However, being a modern concept in international law, Joint Development is relatively new. Furthermore, the definitions provided above have some limitations, either emphasizing on overlapping claims or on general cooperation without specifics.

Because of these, the British Institute of International and Comparative Law, having compared different definitions concerned, defines Joint Development as "an agreement between two States to develop so as to share jointly in agreed proportions by inter-State cooperation and national measures the offshore oil and gas in a designated zone of the seabed and subsoil of the continental shelf to which both or either of the participating States are entitled in international law". ${ }^{12}$ This definition is broad enough to cover all relevant situations which Joint Development is needed and/or required. Generally speaking, the concept of Joint Development contains several characteristics: (a) it is an arrangement between two countries; (b) it is usually concerned with an overlapping maritime area; (c) it can be used as a provisional arrangement pending the settlement of the boundary delimitation disputes between the countries concerned; (d) it is designed to jointly develop the mineral resources in the disputed area or a defined area shared by two countries. In this sense, joint development is a most feasible mechanism to shelf the dispute so as to pave the way of cooperation pending the settlement of the territorial and/or maritime disputes over a certain sea area due to their overlapping claims.

It is necessary to differentiate the concept of joint development from similar concepts such as of unitization which straddles the same structure licensed to two oil companies or of joint venture which is established between, say, a Chinese enterprise and a foreign investor, though the detailed implementation of Joint Development will incorporate features of unitization and/or joint venture agreements. Furthermore, Joint Development carries special meaning and should not be misunderstood simply as something equivalent to joint cooperation either. Finally, while joint development is mainly applicable to the use of mineral resources, it is not excluded in the area of marine living resources management, as manifested in some existing cases, such as the Colombia-Jamaica Treaty of 12 November 1993 which set up a "Joint Regime Area" for joint management, control, exploration and exploitation of the living and

\footnotetext{
${ }^{11}$ Masahiro Miyoshi, "The Joint Development of Offshore Oil and Gas in Relation to Maritime Boundary Delimitation", Maritime Briefing, Vol.2 (5), 1999, at 1. According to Miyoshi, joint development is defined as "an inter-governmental arrangement of a provisional nature, designed for functional purpose of joint exploration for and/or exploitation of hydrocarbon resources of the seabed beyond the territorial sea", ibid., at 3.

${ }^{12}$ British Institute of International and Comparative Law, supra note 7, at 45.
} 
non-living resources, ${ }^{13}$ and the Guinea-Bissau-Senegal Agreement of 14 October 1993 which covers not only oil and gas but also living marine resources. ${ }^{14}$

The LOSC provides a legal basis for joint development in disputed maritime areas pending the settlement of the maritime boundary delimitation. Articles 74 (3) and 83 (3) provide that pending agreement reached between them on the delimitation of the EEZ and continental shelf, the states concerned, in a spirit of understanding and cooperation, are required to "make every effort to enter into provisional arrangements of a practical nature and, during this transitional period, not to jeopardize or hamper the reaching of the final agreement." This legal norm has been reflected in many existing cases and can apply to the East China Sea. However, the LOSC leaves other options open to the states concerned about whether they can enter into joint development agreements after the definite maritime boundary delimitation. It is recalled that as early as 1969 the International Court of Justice (ICJ) touched on this issue in the North Sea Continental Shelf cases by stating that "if... the delimitation leaves to the Parties areas that overlap, there are to be divided between them in agreed proportions or failing agreement, equally, unless they decide on a regime of joint jurisdiction, use, or exploitation for the zone of overlap or any part of them". ${ }^{15}$ Finally, it should be noted that peaceful resolution of international disputes is one of the fundamental principles in international law, as stipulated both in the Charter of the United Nations and the LOSC. Joint Development is one of the options for states to reach a peaceful resolution in the maritime domain. "Provisional arrangements of a practical nature" are designed to promote interim regimes and practical measures that could pave the way for provisional utilization of disputed areas pending delimitation. Such arrangement constitutes an implicit acknowledgment of the importance of avoiding the suspicion of economic development in a disputed maritime area. ${ }^{16}$

In state practice, there are many precedents setting forth the joint development arrangements. The first of this kind was made between Kuwait and Saudi Arabia in 1922, the earliest example of a joint development regime. Based on the 1922 Aqeer Agreement, the two countries were co-tenants in the Neutral Zone, holding shares equally and jointly in

\footnotetext{
${ }^{13}$ See Miyoshi (1999), supra note 11, at 23.

${ }^{14}$ See Miyoshi (1999), supra note 11, at 37.

15 North Sea Continental Shelf Cases, Judgement of 20 February 1969, ICJ Report, 1969, at 53.

${ }^{16}$ Guyana v. Suriname, 17 September 2007, available at http://www.pca-cpa.org/showpage.asp?pag id=1147.
} 
condominium and later on they consented to joint development by their concessionaires ${ }^{17}$ It is summarized that there are generally three types of joint development schemes: (1) to be devised with the maritime boundary delimited, such as the Bahrain-Saudi Arabia Agreement concerning the Delimitation of the Continental Shelf of 22 February 1958, the France-Spain Convention on the Delimitation of the Continental Shelves of the Two States in the Bay of Biscay of 29 January 1974, the Sudan-Saudi Arabia Agreement Relating to the Joint Exploration and Exploitation of the Natural Resources of the Seabed and Subsoil of the Red Sea in a Defined Area of the Two Countries in the Red Sea of 16 May 1974, and the IcelandNorway Agreement on the Continental Shelf between Iceland and Jan Mayen of 22 October 1981; (2) for the purpose of unitizing hydrocarbon deposits which straddle the boundary line, such as the Norway-United Kingdom Agreement Relating to the Delimitation of the Continental Shelf between the Two Countries of 10 March 1965 and its subsequent agreements for the exploitation of Frigg Field gas and Statfjord Field and Murchison Field petroleum respectively; and (3) to be worked out with the issue of boundary delimitation shelved or kept unresolved, such as the Japan-Korea Agreement Concerning Joint Development of the Southern Part of the Continental Shelf Adjacent to the Two Countries of 30 January 1974, the Malaysia-Thailand Memorandum of Understanding on the Establishment of a Joint Authority for the Exploitation of Resources of the Seabed in a Defined Area of the Two Countries in the Gulf of Thailand of 21 February 1979 (followed by the 1990 Malaysia-Thailand Joint Development Agreement), and the Australia-Indonesia Treaty on the Zone of Cooperation in an Area between the Indonesian Province of East Timor and Northern Australia of 11 December 1989 (now superseded by the 2002 AustraliaTimor Leste Agreement). ${ }^{18}$ The third type is linked to the provisional arrangements stipulations under the LOSC.

Some existing joint development models are conducive to the initiation and development of a similar one for the East China Sea. They actually exist all over the world from the North Sea Model to the Arabic Sea, and from Asia to Latin America. ${ }^{19}$ In the East Asian region, joint development is also a mode of bilateral cooperation between the countries concerned,

\footnotetext{
${ }^{17}$ See Ibrahim F.I. Shihata \& William T. Onorato, "Joint Development of International Petroleum Resources in Undefined and Disputed Areas", in G.H. Blake, M.A. Pratt \& C.H. Schofield (eds.), Boundaries and Energy: Problems and Prospects (London: Kluwer Law International, 1998), 436-437.

${ }^{18}$ Masahiro Miyoshi, "Is Joint Development Possible in the South China Sea?" in Mochtar Kusuma-Atmadja, Thomas A. Mensah and Bernard H. Oxman (eds.), Sustainable Development and Preservation of the Oceans: The Challenges of UNCLOS and Agenda 21 (Honolulu: the Law of the Sea Institute, University of Hawaii, 1997), 613-614.

${ }^{19}$ For details of some existing cases, see Miyoshi (1999), supra note 11, 7-41.
} 
such as the Japan-South Korean Arrangement in the Sea of Japan and the East China Sea in the 1970s, the Malaysia-Thailand Joint Development Area in the Gulf of Thailand and the Australian-Indonesia Joint Development Zone for the Timor Gap. ${ }^{20}$

What is more significant is the joint arrangement made by three countries - Malaysia, Thailand and Vietnam - in the Gulf of Thailand for their overlapping claimed sea areas where the three countries agreed in 1999 on establishing a regime of joint development. When the tripartite accord becomes effective, it will be the first multilateral agreement on joint development. ${ }^{21}$ The tripartite agreement, however, is based on two associated bilateral agreements either between Malaysia and Thailand or between Malaysia and Vietnam. In 1979, Malaysia and Thailand signed a Memorandum of Understanding (MOU) to establish, on an interim basis of 50 years, a Malaysia-Thailand Joint Authority "for the purpose of the exploration and exploitation of the non-living natural resources of the seabed and subsoil in the overlapping area". ${ }^{22}$ More than ten years later, the two countries worked out the Constitution and other matters relating to the establishment of such an authority, which provides details of the operation in the joint zone. ${ }^{23}$ There are two striking characteristics in this joint development scheme: a powerful joint authority which decides on the plan of operation and the work program, to permit operations and conclude transactions or contracts, to approve and extend the period of exploration and exploitation, to approve the work program and budgets of the contractor, and inspect and audit the operator's books and accounts, ${ }^{24}$ and the introduction of a production sharing system which include such terms and conditions as the duration of the contract not exceeding 35 years, the payment of $10 \%$ of gross production of petroleum by the contractor to the Joint Authority as royalty, $50 \%$ of gross production to be applied by the contractor for the recovery of costs, the remainder of gross production to be profit and divided equally between the Joint Authority and the contractor, all costs of operations to be borne by the contractor, and any dispute arising out of the contract to be referred to arbitration unless settled amicably. ${ }^{25}$

\footnotetext{
${ }^{20}$ For details, see Shihata \& Onorato, supra note $16,438-441$.

${ }^{21}$ Nguyen Hong Thao, "Vietnam and Joint Development in the Gulf of Thailand", Asian Yearbook of International Law, Vol.8, 2003, 138-139.

${ }^{22}$ Text is reprinted in Jonathan I. Charney and Lewis M. Alexander (eds.), International Maritime Boundaries (Dordrecht: Martinus Nijhoff Publishers, 1993), Vol.1, 1099-1123.

${ }^{23}$ See Ibid. For further details, see David M. Ong, "The 1979 and 1990 Malaysia-Thailand Joint Development Agreements: A Model for International Legal Co-operation in Common Offshore Petroleum Deposits?" International Journal of Marine and Coastal Law, Vol. 14 (2), 1999, 207-246. 24 See Article 7 of the 1990 Agreement.

${ }^{25}$ See Article 8 of the 1990 Agreement.
} 
On the other hand, Malaysia and Vietnam also signed a MOU in 1992 for joint development in the Gulf of Thailand. Accordingly Petronas and Petrovietnam are assigned to undertake respectively petroleum exploration and exploitation in the "defined area". The arrangement between the two state-owned oil companies made in August 1993 established an 8-member Coordination Committee to issue policy guidelines for the management of petroleum operations. This is different from the Thai-Malaysia model in which the Joint Authority is appointed directly by the governments. After the conclusion of the commercial arrangement in July 1997, oil has been extracted from the Bunga Kekwa field. ${ }^{26}$ Based on the bilateral arrangements, a tripartite mechanism has been gradually evolving for an overlapping maritime area. This practice shows that a form of multilateral joint development is possible and realistic.

More significant are agreements concerning maritime boundary delimitation since joint development is usually invoked in state practice as a provisional measure pending the settlement of boundary delimitation. In this sense, the 2000 Agreement on the Maritime Boundary Delimitation in the Gulf of Tonkin between China and Vietnam is notable. In addition to the settlement of the maritime boundary issue in the Gulf of Tonkin permanently, it reflects the idea of joint development of mineral resources in the gulf as it provides that

In case any single geophysical structure of oil and gas or other mineral deposits straddles the demarcation line as provided in Article 2 of this Agreement, the Parties shall, through friendly consultation, reach an agreement on develop the structure or deposit in the most effective way as well as on equal sharing of the profits resulting from the development. ${ }^{27}$

The above existing experiences in formulating joint development mechanisms no doubt help to establish a similar arrangement for the disputed areas in the East China Sea.

\section{Legal Positions on the Law of the Sea}

At the domestic level, China has taken several legislative moves in response to the implementation of the LOSC. In 1992 China promulgated the Law on the Territorial Sea and

\footnotetext{
${ }^{26}$ See Nguyen Hong Thao, supra note 21, at 145.

${ }^{27}$ Article 7 of the 2000 Boundary Agreement. An unofficial English version of this Agreement is attached to Zou Keyuan, "Sino-Vietnamese Agreement on the Maritime Boundary Delimitation in the Gulf of Tonkin", Ocean Development and International Law, Vol.36, 2005, 13-24.
} 
the Contiguous Zone ${ }^{28}$ which has improved the territorial sea regime established under the 1958 Declaration on the Territorial Sea. China has set its territorial sea at a breadth of $12 \mathrm{~nm}$ and the contiguous zone of $24 \mathrm{~nm}$, measuring from the coastal baselines. This law applies to all of China, including Taiwan and the various islands located in the China seas.

Another basic marine law is the Law on the Exclusive Economic Zone and the Continental Shelf which was adopted by the National People's Congress in 1998. ${ }^{29}$ This law is designed to guarantee China's exercise of sovereign rights and jurisdiction over its EEZ and continental shelf, and to safeguard China's national maritime rights and interests. According to this law, China's EEZ is the area beyond and adjacent to China's territorial sea, extending up to 200 nautical miles from baselines from which the breadth of the territorial sea is measured. As for China's continental shelf, it comprises the sea-bed and subsoil of the submarine areas that extend beyond China's territorial sea throughout the natural prolongation of its land territory to the outer edge of the continental margin, or to a distance of 200 nautical miles from the baselines from which the breadth of the territorial sea is measured where the outer edge of the continental margin does not extend up to that distance. ${ }^{30}$ It is interesting to note that although the provision to define the EEZ is just a copy of the relevant provision of the LOSC, the provision regarding the continental shelf has something new with Chinese characteristics, that is, the emphasis on the natural prolongation of China's rights to the continental shelf, which bears strong implications for the delimitation of the continental shelf in the East China Sea. ${ }^{31}$ The Law further provides that EEZs and continental shelves with overlapping claims between China and the countries with opposite or adjacent coasts should be determined by agreement in accordance with the equitable principle on the basis of international law.

In May 1996 when ratifying the LOSC, China issued a declaration on its baselines. China uses the method of straight baselines to define the limits of its territorial sea around part of the mainland and the Xisha (Paracel) Islands. ${ }^{32}$ Meanwhile, China stated that it would announce remaining baselines of its territorial sea at another time.

\footnotetext{
${ }^{28}$ The English version may be found in Office of Ocean Affairs, Bureau of Oceans and International Environmental and Scientific Affairs, US Department of State, Limits in the Seas, No.117 (Straight Baselines Claim: China), July 9, 1996, 11-14.

${ }^{29}$ The Chinese text is reprinted in People's Daily (in Chinese), 30 June 1998. An English translation may be found in Law of the Sea Bulletin, No.38, 1998, 28-31.

${ }^{30}$ Article 2 of the Law on EEZ and Continental Shelf.

${ }^{31}$ Zou Keyuan, China's Marine Legal System and the Law of the Sea (Leiden: Martinus Nijhoff, 2005), at 94.

32 Declaration on the Baseline of the Territorial Sea of the People's Republic of China, 15 May 1996, see Office of Ocean Affairs, supra note 28, 9-10.
} 
In the Decision on the Ratification of the United Nations Convention on the Law of the Sea, China made a statement that:

1. In accordance with the provisions of the United Nations Convention on the Law of the Sea, the People's Republic of China shall enjoy sovereign rights and jurisdiction over an exclusive economic zone of 200 nautical miles and the continental shelf.

2. The People's Republic of China will effect, through consultations, the delimitation of the boundary of the maritime jurisdiction with the States with coasts opposite or adjacent to China respectively on the basis of international law and in accordance with the principle of equitability.

3. The People's Republic of China reaffirms its sovereignty over all its archipelagos and islands as listed in article 2 of the Law of the People's Republic of China on the territorial sea and the contiguous zone, which was promulgated on 25 February 1992. ${ }^{33}$

The above statement clearly shows the official position of China regarding the maritime boundary delimitation and reiterates its claims to the disputed islands in the East and South China Seas. In July 2013, President Xi Jinping expressed that his government was willing to shelve territorial disputes and carry out joint development in disputed waters. ${ }^{34}$

Japan took the similar domestic legislation process. In 1977 it adopted the Law on Territorial Sea and in 1996 the Law on EEZ and Continental Shelf. What it has done more than China is its promulgation of the Basic Ocean Law in 2007, which provides legal guidance for a unified and comprehensive ocean policy and administration. ${ }^{35}$ Regarding maritime boundary delimitation with neighbouring countries, Japan has advocated the application of the median line as a delimitation line for the EEZ and the continental shelf in the absence of an agreed line with the opposite country. This is reflected in its 1996 EEZ Law. ${ }^{36}$

The above legal positions have direct impact on the negotiation of any maritime cooperative mechanisms including schemes for joint development in the East China Sea.

\footnotetext{
33 The declaration is available at http://www.un.org/Depts/los/convention agreements/convention declarations.htm\#China\%20after\%20ratifi cation.

${ }^{34}$ See "China Willing to Pursue Joint Development in Disputed Waters", 31 July 2013, available at http://www.voanews.com/content/china-willing-to-pursue-joint-development-in-disputedwaters/1713906.html.

${ }^{35}$ A Chinese translated version is available at China Oceans Law Review, 2008, No.1, 128-133.

${ }^{36}$ See Article 1 (2) and Article 2 (2) of the Law on the Exclusive Economic Zone and the Continental Shelf (Law No.74 of 1996), Law of the Sea Bulletin, No.33, 1997, 94-95.
} 


\section{Korea-Japan Joint Development Agreement}

The Japanese-South Korean joint development arrangement was the first as such in East Asia. The arrangement was based on several agreements signed between the two countries. It is significant in state practice since it represents the first application of the idea of joint development of offshore oil where the parties failed to agree on boundary delimitation. ${ }^{37}$ Under the agreement, concessionaires who are authorized by the two respective governments have an undivided interest with respect to each of the nine defined sub-zones, and one operator is chosen from among the concessionaires so authorized for a particular sub-zone. ${ }^{38}$ However, the "operator formula" which shifts applicable law to the operator from Japan to Korea or vice versa brings inconveniences to the operator when it transfers its work from one sub-zone to another sub-zone. The agreement establishes a Joint Commission as a consultative body to implement the agreement.

China (PRC) strongly protested this “joint development" arrangement and condemned it as an encroachment on China's sovereignty. ${ }^{39}$ It was regarded by China as invalid, illegal and no binding force on a third state. ${ }^{40}$ On the other hand, China stated that the method of delimiting the continental shelf areas in the East China Sea should be determined by consultation between all the countries concerned. While it is not clear whether by that statement China meant a trilateral consultation, it could be interpreted as suggesting a multilateral approach which would be conducive to similar consultations for the South China Sea disputes. ${ }^{41}$ There is an interesting background to this approach. Originally the Taiwan Chinese were involved in the discussions of possible joint development in the East China Sea. In November 1970, a Japan-South Korea-ROC Liaison Committee was formed and later this organization was renamed as the Sino-Japanese-Korea Joint Committee for Ocean Development Research. However, this cooperation initiative ended in September 1972 when Taipei withdrew from the committee in the wake of Tokyo's recognition of Beijing. ${ }^{42}$ Should any arrangement have been made between the three sides, it would have generated strong

\footnotetext{
${ }^{37}$ Miyoshi (1999), supra note 11 , at 1.

38 Miyoshi, ibid., at 12.

${ }^{39}$ See the Statement of the PRC Ministry of Foreign Affairs, 4 February 1974, reprinted in Law Department of Peking University (ed.), Collected Materials on the Law of the Sea (Beijing: People's Press, 1974) (in Chinese), at 88.

40 See Zhao Lihai, Studies on the Law of the Sea (Beijing: Peking University Press, 1996) (in Chinese), at 55.

${ }^{41}$ See Masahiro Miyoshi, "International Maritime Boundaries and Joint Development: A Quest for a Multilateral Approach", in G.H. Blake, M.A. Pratt \& C.H. Schofield (eds.), supra note 17, at 465.

${ }^{42}$ Hurng-yu Chen, "The Prospects for Joint Development in the South China Sea", Issues and Studies, Vol.27

(12), 1991, at 122.
} 
repercussions in East Asia, both legally and politically. One of the reasons why China (PRC) strongly protested the bilateral arrangement between Japan and South Korea may be attributed to the early involvement of the Taiwanese side.

There has to date no discovery of commercially viable hydrocarbons.

\section{China-Japan Principled Consensus}

In the East China Sea, China and Japan discussed the possibility of joint development of petroleum resources in the disputed areas. After China began to explore the Chunxiao gas field, Japan expressed its discontent and accused China of encroaching upon Japan's rights in the East China Sea. The two sides held their consultation on 25 October 2004. At the sixth round of consultation in July 2006, the two sides reached a consensus to establish a maritime hotline communication mechanism in dealing with unexpected matters. ${ }^{43}$ During the following consultation, China put forward two proposals on joint development in the East China Sea but Japan only considered the one in the northern sea area. ${ }^{44}$

A consensus agreement was reached in June 2008 regarding joint development in the East China Sea after 11 rounds of negotiation (see Table 7.1). Accordingly, the agreed consensus includes (a) bilateral cooperation in the East China Sea and turning it into a sea of peace, cooperation and friendship; (b) joint development in the East China Sea and a small patch of joint development zone has been identified; a block of about 2,600 sq km that straddles the median line claimed by Japan and (c) participation of Japanese legal person in the development of Chunxiao Oil and Gas Field in accordance with Chinese laws. ${ }^{45}$ The conclusion of this agreement is in line with the spirit and provisions of the LOS Convention which encourages States concerned to work out provisional arrangements including joint development agreement pending the settlement of their maritime boundary disputes.

However, the designated maritime zone for joint development is just a small patch and China is currently reluctant to go further with the implementation of this consensus agreement.

\footnotetext{
43 "China and Japan reached the principle consensus on establishing maritime hotline", available at http://world.people.com.cn/GB/4572649.html.

44 "Japan consider accepting the proposal on joint development in the northern sea area in the East China Sea", 15 May 2006, available at http://world.people.com.cn/GB/1029/42354/4371017.html. 45 "China, Japan reach principled consensus on East China Sea issue", 18 June 2008, available at http://www.chinadaily.com.cn/china/2008-06/18/content 6774860.htm. See Gao Jianjun, "A Note on the 2008 Cooperation Consensus Between China and Japan in the East China Sea", Ocean Development and International Law, Vol.40, 2009, 291-303.
} 
A tentative agreement was scheduled to be finalised in September 2013. However, when the China-Japan political relations soured over the collision of a Chinese fishing vessel with a Japanese Coast Guard vessel, China asked for an indefinite postponement of the joint development agreement signing. While China still favors joint development, it has expressed that the resumption of talks on gas development would require Japanese concessions on bilateral issues, such as the dispute over the Diaoyu Islands.

\section{Implications of Fishery Agreements for Joint Development}

Since the broadest width of the East China Sea is less than $400 \mathrm{~nm}$, the whole sea area becomes EEZs that are shared by China, Japan and Korea. The fishery relationship between the two sides inevitably needed a new adjustment. After several rounds of negotiation, the China and Japan finally reached agreement in September 1997 regarding the fishery management in the East China Sea. ${ }^{46}$ The new agreement came into force on 1 June 2000.

The agreement contains some significant provisions in response to the changed situation: (a) affirming the principle of fishery resources conservation and protection: Pursuant to the relevant provisions in the LOSC and environmental requirements from Agenda 21 and others, the Agreement contains as one of its purposes the establishment of a new fishery order in accordance with the LOSC, conserving and utilising rationally marine living resources of common concern, and maintaining the normal operation order at sea. Both sides agree to cooperate to conduct scientific research in fishery and to conserve marine living resources. ${ }^{47}$ Each should adopt necessary measures to ensure compliance by their nationals and fishing boats with the provisions of the Fishery Agreement and the conservation measures and other conditions provided for in the relevant laws and regulations of the other Party when they are engaged in fishery activities in the other's EEZ, and should inform each other of such conservation measures and other conditions provided for in its relevant laws and regulations. ${ }^{48}$ (b) Providing reciprocal fishing rights: The Agreement applies to the EEZs of both countries. However, this does not include all the EEZs as the Agreement excludes the EEZ area south of $27^{0} \mathrm{~N}$, and west of $125^{0} 30^{\prime} \mathrm{E}$ in the East China Sea where Taiwan and the

\footnotetext{
${ }^{46}$ Fishery Agreement between the People's Republic of China and Japan, 11 November 1997. An unofficial English translation is available in Zou Keyuan, Law of the Sea in East Asia: Issues and Prospects (London: Routledge, 2005), 175-180.

${ }^{47}$ Article10 of the Sino-Japanese Fishery Agreement.

${ }^{48}$ Article 4 of the Sino-Japanese Fishery Agreement.
} 
disputed Diaoyu/Senkaku Islands are located. (c) Establishing the Provisional Measures Zone (PMZ): The Agreement creates the PMZ which is located in the middle of the East China Sea, $52 \mathrm{~nm}$ from the baselines of the territorial seas for the Chinese mainland coast and for the coast of the Ryukyu Islands with its northern limit on the parallel of $30^{\circ} 40^{\prime} \mathrm{N}$ and its southern limit on the parallel of $27^{0} \mathrm{~N}$. For conservation and quantity of fishery resources in the PMZ, both sides should adopt, based on decisions made by the Sino-Japanese Fishery Joint Committee, appropriate management measures in order to protect marine living resources from the harm of being overexploited. Each party should take administrative and other necessary measures for its nationals and fishing boats fishing in the PMZ, and should not impose administrative and other measures on nationals and fishing boats of the other Party in this water area. The establishment of a common fishery zone is a typical form of fishery cooperation for shared waters between any two countries. What is new is that the PMZ is the first such zone between China and Japan, though there was some kind of fishery cooperation between the two sides in history.

It is the first such agreement between China and its neighboring countries concluded after the establishment of the EEZ regime. It is a positive sign favoring joint development in marine mineral resources.

\section{Implications of Extended Continental Shelf for Joint Development}

Article 76 of the LOSC provides the criteria to determine the outer limit of the continental shelf up to $350 \mathrm{~nm}$ from the baselines from which the breadth of the territorial sea is measured or $100 \mathrm{~nm}$ from the 2,500 metre isobath:

(i) a line delineated by reference to the outermost fixed points at each of which the thickness of sedimentary rocks is at least 1 per cent of the shortest distance from such point to the foot of the continental slope; or

(ii) a line delineated by reference to fixed points not more than 60 nautical miles from the foot of the continental slope.

The deadline for any submission from a coastal State, which became the party to the LOSC before 13 May 1999, on its outer continental shelf to the Commission on the Limits of the Continental Shelf was 13 May 2009 (for East Asian countries, see Table 7.2). The Commission has a function to consider the data and other material submitted by coastal States concerning the outer limits of the continental shelf in areas where those limits extend beyond 
200 nautical miles, and to make recommendations in accordance with Article 76 of the LOSC and the Statement of Understanding adopted on 29 August 1980 by the Third United Nations Conference on the Law of the Sea. Accordingly, Japan submitted its claim on 12 November 2008 .

On 6 February 2009, China lodged its objection to part of the Japanese submission regarding the Oki-no-Tori Shima, which, in China's view, is in fact a rock which does not have any ground to claim continental shelf and requests the Commission not to take any action on the portions extended from that rock. ${ }^{49}$ South Korea shared the same view as the Chinese. However, the Commission is not the body which has the mandate to interpret the provisions of the LOSC as it reiterated that it had no role on matters relating to the legal interpretation of Article 121 of the Convention. ${ }^{50}$ On the other hand, if there is a dispute regarding a submission between different countries, the Commission has no mandate to review such a submission.

In addition, in May 2009 China and Republic of Korea both submitted respectively their Preliminary Information regarding their outer continental shelf in the East China Sea to the Commission on the Limits of the Continental Shelf in accordance with relevant provisions of the LOSC and other decisions made by the State Parties Conferences on the Law of the Sea. ${ }^{51}$ The two countries have met the requirement and the submission of the preliminary information enables them to make their full submissions in a later time. Since such preliminary information indicates that both China and Korea's outer continental shelf claims are in the East China Sea, it surely affects the interests of Japan who lodged protests with the United Nations. Furthermore, since they are both in the East China Sea, their claims are in conflict with each other as well. Following their Preliminary Information, China and South Korea submitted their outer continental shelf claims to the CLCS in the East China Sea in December 2012, which was objected by Japan. ${ }^{52}$

\footnotetext{
${ }^{49}$ China's Objection is available at http://www.un.org/Depts/los/clcs new/submissions files/jpn08/chn 6feb09 e.pdf.

50 "Statement by the Chairman of the Commission on the Limits of the Continental Shelf on the progress of work in the Commission", CLCS/64, 1 October 2009, available at http://daccess-dds-ny.un.org/doc/UNDOC/GEN/N09/536/21/PDF/N0953621.pdf?OpenElement.

${ }^{51}$ For details on China's submission, see http://www.un.org/Depts/los/clcs new/submissions files/preliminary/chn2009preliminaryinformation englis h.pdf and on Korea's submission, see http://www.un.org/Depts/los/clcs new/submissions files/preliminary/kor 2009preliminaryinformation.pdf. ${ }^{52}$ For details, see http://www.un.org/Depts/los/clcs new/commission_submissions.htm.
} 
In April 2014, when the Chinese scientific investigation vessel "Science" was conducting its WPOS project around the Okinawa Trough, the Japanese Coast Guard asked the Chinese side to stop its activities as it is within the EEZ of Japan. However, according to China, the area is the natural prolongation of China's continental shelf. ${ }^{53}$ It is indicated that the disputes concerning maritime boundary delimitation will continue.

\section{Third Party Interest}

Maritime issues are usually affecting the interest of third parties. In the East China Sea, China lodged a strong protest against the establishment of a Japan-Korea Joint Development Zone in the East China Sea in the 1970s. Likewise, the bilateral fishery agreement between China and Japan or between Japan and Korea also affected the interests of the other party as any bilateral arrangement may affect other relations and interests since they share the same sea area and use the same pool of marine living resources.

When Japan and Korea concluded their new fishery agreement, China considered that the Japan-Korea Fishery Agreement encroached on China's sovereign rights over its EEZ in the border areas among the three countries and stated that China's rights and interests in the EEZ and its fishery activities should not be subject to the limitation of that agreement. China maintained that the delimitation of the overlapping area among the three countries should be subject to consultations among the parties concerned, and exclusion of any party from the delimitation negotiations would be a violation of international law. ${ }^{54}$ On the other hand, South Korea also expressed its dissatisfaction with the Sino-Japanese Fishery Agreement by asking China and Japan to explain how they drew the northern-limit line of their joint fishing area. They should consult South Korea before reaching the agreement. ${ }^{55}$

On the other hand, it has to be realised that the fishery agreements either between China and Japan, or China and South Korea, or Japan and South Korea are bilateral ones. They have limitations and also do not completely cover the areas in the East China Sea and the Yellow

\footnotetext{
53 See “中国科考船在冲绳海槽遭日阻挠与东海划界相关”, 15 April 2014, available at http://scitech.people.com.cn/n/2014/0415/c1057-24895134.html.

54 "MF Spokesman expresses that the Japan-Korea Fishery Agreement encroaches on China's sovereign rights over its EEZ", People's Daily (in Chinese), 23 January 1999. For further reference, see Fan Xiaoli, "Comments on the New Japan-Korea Fishery Agreement", Ocean Development and Management (in Chinese), Vol.17 (1), 2000, 68-70.

${ }^{55}$ See Chi Young Pak, "Resettlement of the Fisheries Order in Northeast Asia resulting from the New Fisheries Agreements among Korea, Japan and China", Korea Observer, Vol.30 (4), 1999, 614-615. For other related reference, see Mark J. Valencia and Yong Hee Lee, "The South Korea-Russia-Japan Fisheries Imbroglio", Marine Policy, Vol.26, 2002, 337-343.
} 
Sea. Second, because of the bilateral nature, they may affect the interests of a third party as illustrated above in the Japan-Korean Fishery Agreement. Third, since bilateral agreements only regulate bilateral relations, fishing activities of third parties are outside any regulation. This is particularly true when Taiwan is concerned. Finally, many fishery resources in the East China Sea and the Yellow Sea are migratory species so that they belong to the same marine ecosystem. In that sense, the East Asian seas urgently need a regional and multilateral fishery arrangement which can be more effective to conserve and manage the fishery resources therein, and the newly concluded bilateral fishery agreements including the SinoJapanese one could be the basis for such regional cooperation.

\section{Taiwan Factor}

The Taiwan factor is deterrent to the smooth settlement of maritime disputes between China and some of its maritime neighbors. The 1997 Sino-Japanese Fishery Agreement deliberately avoided its coverage over the sea area surrounding Taiwan. On the other hand, Taiwan has raised the issue of overlapping areas in the Bashi Channel with the Philippines many times, hoping to reach an agreement. However, since the Philippines has recognized the PRC as the sole legitimate government of China and any such deal should be done with Beijing rather than with Taipei, the issue could not be easily resolved. ${ }^{56}$ Since all the neighboring countries recognize the PRC as the sole legitimate government of China, the delimitation negotiations must be conducted between those countries and the PRC without the involvement of Taiwan, the situation of the divided China remains a major obstacle to resolving the maritime boundary issues between China and its neighboring countries, particularly Japan and the Philippines.

It is recalled that in 1974, Japanese Prime Minister Kakuei Tanaka sought an international agreement for oil exploration and extraction around Senkaku/Diaoyu Islands which would include China and Taiwan. But there was little chance of the PRC agreeing to participate in any scheme in which Taiwan was included as an equal and independent partner.

On 10 April 2013 Japan and Taiwan concluded the Fishery Agreement after 16 rounds of talks since 1996. Some factors behind it include Ma Ying-jeou's East China Sea Peace

\footnotetext{
${ }^{56}$ See Fu Kuen-chen, "Dispute over the Detention of Fishing Vessels in the Law of the Sea Perspective", Youth Daily (in Chinese), 8 May 1989; and see also James T. Shen, Political and Legal Implications of the Concept of the Exclusive Economic Zone as Applied to the Republic of China (Taipei: Cross-Strait Interflow Prospect Foundation, 1998), at 30.
} 
Initiative for Taiwan's foreign policy; and Japan's desire to place a wedge between China and Taiwan, preventing them from forming a united front against Japan's interests.

On 5 August 2012, Taiwanese President Ma Ying-jeou put forward the 5-point East China Sea Peace Initiative. ${ }^{57}$ In September 2012, Taiwan issued the Implementing Guidelines. Point 5 is related to joint development as it proposes to "establish a mechanism for cooperation on exploring and developing resources in the East China Sea.

\section{A Possible Tripartite Agreement?}

As we know, there is no substantial progress concerning the bilateral arrangements for joint development in the East China Sea, either between Japan-South Korea or between China and Japan. In that circumstance, shall we consider an alternative to see the possibility of joint development in the East China Sea? Is it possible to work out a trilateral scheme for joint development among China, Japan and South Korea in the East China Sea? The advantage for a three-party cooperative mechanism is that it can accommodate the interests of all parties so as to avoid conflict of interests. But the disadvantage lies in the fact that such agreement is more difficult to work out and to be implemented

Existing experiences regarding trilateral cooperation include the South China Sea Experience and the Gulf of Thailand Experience: On 11 November 2003, the CNOOC and the Philippine National Oil Company agreed to jointly explore oil and gas in the South China Sea through the signing of a letter of intent between the two sides. A joint committee was set up to help select exploring areas in the South China Sea. They also agreed to establish a program to "review, assess and evaluate relevant geographical, geophysical and other technical data available to determine the oil and gas potential in the area". ${ }^{58}$ Following this development, the State-owned oil companies of China, the Philippines and Vietnam (CNOOC, PetroVietnam and Philippine National Oil Company) signed an agreement on joint seismic exploration in a designated area $\left(143,000 \mathrm{~km}^{2}\right)$ of the South China Sea in March 2005. ${ }^{59}$ However, after the first stage of the joint seismic survey, there has been no follow-up activity sponsored by the above three countries. Apparently, this preliminary joint

\footnotetext{
${ }^{57}$ Full text is available at $\mathrm{http} / / /$ www.mofa.gov.tw/en/cp.aspx? $n=A 3 C 75 D 6 C F 8 A 0 D 021$.

58 "Chinese, Philippine firms join forces to look for oil in South China Sea", Agence France Presse, 13 November 2003.

${ }^{59}$ See "China, Philippines and Vietnam sign agreement to explore oil in the South China Sea", LianheZaobao, 15 March 2005, available at http://www.zaobao.com/gi/yx501_150305.html.
} 
development scheme has encountered a political stalemate resulting from distrust and conflict of maritime interests.

As for the Gulf of Thailand Experience, it involves three countries, i.e., Malaysia, Thailand and Vietnam. According to the 1997 Thailand-Vietnam maritime boundary agreement, the two countries, together with Malaysia "shall enter into negotiations in order to settle the tripartite overlapping continental shelf claim area”. In 1999 the three countries agreed in principle on JD for a small overlapping area, but there is no progress so far.

As we know, China, Japan and Korea have already conducted trilateral cooperation. In addition to the ASEAN Plus Three institutional arrangement, the three countries signed a trilateral agreement on 16 December $2010 .^{60}$ The Agreement is designed to contribute to the further promotion of cooperative relations among the three countries by providing support for the cooperation and management of the trilateral consultative mechanisms among the Parties and by facilitating the exploration and implementation of cooperative projects. It set up the Trilateral Cooperation Secretariat in Seoul in September 2011. Since 2010, the cooperative areas have covered disaster management, sustainable forest management, nuclear safety, and agricultural cooperation. ${ }^{61}$ It is reasonably assumed that with the expansion of the cooperative areas, the three countries could consider putting on the agenda the possible joint development in the East China Sea.

\section{Conclusion}

Joint development is mainly used as an interim measure pending the settlement of territorial and/or maritime disputes. Joint development can help stabilize the status quo of the disputed area, and may finally lead to a permanent dispute resolution. Unless such a resolution comes true, the disputes will be still there. It may on the other hand affect from time to time the effective implementation of any joint development arrangement.

It is clear that joint development between two states in the areas with multiple claims causes problems. It is called that when Japan and South Korea signed the joint development agreement for the East China Sea, it invited furious protests from China. The 2003 move

\footnotetext{
${ }^{60}$ Full text is available at http://file.tcsasia.org/file manager/files/tcs/1.\%20Basic\%20Documents/1.\%20English/(2010.12.16)Agreement\%20on\%20th e\%20Establishment\%20of\%20the\%20Trilateral\%20Cooperation\%20Secretariat.pdf.

${ }^{61}$ For details, see http://www.tcs-asia.org/dnb/board/list.php?board name=3 $5 \quad 1$ documents 1.
} 
between China and the Philippines regarding the possible joint development in the South China Sea met with protests from Vietnam. For that reason, joint development launched by only two claimant countries may not be an optimal option. On the other hand, joint development proposals at the bilateral level may not always welcome by relevant claimants. It is recalled that China once proposed to have a joint development with Vietnam for the Vanguard Bank where part of the area was a concession given to Crestone by China, but Vietnam rejected China's proposal on the ground that the area is close to Vietnamese coastlines and within the limits of its continental shelf. ${ }^{62}$

All the states surrounding the East China Sea are demanding for energy for their economic growth. The increased energy consumption will definitely make the claimants to be more actively involved in oil and gas exploration and exploitation. This may cause more conflicts amongst the claimants if any of them conduct unilateral petroleum activities in the disputed maritime area. But it could create a window of opportunity for joint development when the claimants have realized that the unilateral act becomes a costly, disturbing and unfeasible option. All countries concerned should discuss a regional cooperation framework for joint development in the East China Sea. Once a form of joint development has been reached, relatively long-term peace and security in the East China Sea can be definitely guaranteed, which may positively lead to the final settlement of the territorial and maritime disputes in the area.

Table 7.1: Rounds of Negotiation on the East China Sea Dispute

\begin{tabular}{lll}
\hline Round & Time & Venue \\
\hline 1 & 25 October 2004 & Beijing \\
2 & 30-31 May 2005 & Beijing \\
3 & 30 Sept. -1 Oct. 2005 & Tokyo \\
4 & 6-7 March 2006 & Beijing \\
5 & 18 May 2006 & Tokyo \\
6 & 8-9 July 2006 & Beijing \\
7 & 29 March 2007 & Tokyo \\
8 & 25 May 2007 & Beijing \\
9 & 26 June 2007 & Tokyo \\
10 & 11 October 2007 & Beijing \\
11 & 14 November 2007 & Tokyo \\
\hline
\end{tabular}

62 Hasjim Djalal, "The Relevance of the Concept of Joint Development to Maritime Disputes in the South China Sea", Indonesian Quarterly, Vol.27 (3), 1999, at 180. 
Source: compiled by the author.

Table 7.2: Dates of Submission in East Asia

\begin{tabular}{lcl}
\hline State & Dates & Submission \\
& & \\
Brunei & $12 / 05 / 09$ & Preliminary Info \\
China & $11 / 05 / 09$ & Preliminary Info \\
& $14 / 12 / 12$ & Partial Submission \\
Indonesia & $16 / 06 / 08$ & Partial Submission \\
Japan & $12 / 11 / 08$ & Full Submission \\
Malaysia & $06 / 05 / 09$ & Joint Submission \\
Philippines & $08 / 04 / 09$ & Partial Submission \\
South Korea & $11 / 05 / 09$ & Preliminary Info \\
& $26 / 12 / 12$ & Partial Submission \\
Vietnam & $06 / 05 / 09$ & Joint Submission \\
& $07 / 05 / 09$ & Partial Submission \\
\hline
\end{tabular}

Source: compiled by the author. 